\title{
Development and optimization of the jam production process of Pouteria cf. gardneriana Radlk (guapeva)
}

\author{
Camila Mariane da Silva SOARES ${ }^{1}$, Rômulo Alves MORAIS ${ }^{1}$, Romilda Ramos da SILVA ${ }^{1}$, \\ Bárbara Catarina Bastos de FREITAS ${ }^{1}$, Antonio Alves de MELO FILHO ${ }^{2}$, Glêndara Aparecida de Souza MARTINS ${ }^{1,3 *}$
}

\begin{abstract}
This work aimed to study the effect of citric acid and passion fruit albedo concentrations and pulp/sugar ratio in optimizing of jam production process of Pouteria cf. gardneriana Radlk (guapeva fruit) and evaluating the nutritional characteristics and functional properties of the developed jams. A factorial design $2^{3}$ with 11 assays was used, considering citric acid concentration, pulp/sugar ratio, and albedo concentration as independent variables. Formulations containing a 50/50 pulp/sugar ratio proved to be excellent for quality parameters, the potential of phenolic compounds, antioxidants, and sensory properties. The formulation indicated as most desirable was the one containing a 40/60 sugar/pulp ratio. Guapeva proved to be a good alternative for jam production because even after thermal processing, it was possible to obtain jams rich in Vitamin C, phenolic compounds, and antioxidant potential.
\end{abstract}

Keywords: bioactive compounds; cerrado fruit; nutritional composition; passion fruit albedo.

Practical Application: Citric acid and pulp/sugar ratio positively affect the development of guapeva jam.

\section{Introduction}

With an immeasurable heritage, the Brazilian Cerrado is considered one of the richest biomes in the world that assemble a number of exotic native fruits, rich in bioactive compounds associated with antioxidants, anti-inflammatory, antitumor, antimicrobial and antigenotoxic properties (Schiassi et al., 2018; Li et al., 2016). The properties of these fruits make them potential sources to the development of new products for the food industry (Morzelle et al., 2015). However, countless fruits are still little explored commercially and scientifically (Silva et al., 2017), as is the case of Pouteria cf. gardneriana Radlk, which has favorable characteristics to contribute to a healthy diet.

The guapeva fruit belongs to the Pouteria Genus from the Sapotaceae family. The high technological potential is derived from its peel and pulp rich in antioxidants and phenolic compounds (Barbosa et al., 2016). Its fruits can be used in food preparation, contributing to the intake of nutrients that can help to prevent the development of chronic degenerative diseases, such as cancer and diabetes, in addition to not showing toxicological levels when tested on animals (Siqueira et al., 2017; Malta et al., 2013). However, the use of this fruit is still little explored due to the lack of knowledge about its benefits.

Based on this scenario, this work aimed to study the effect of citric acid and passion fruit albedo concentration, as well as pulp/sugar ratio in optimizing the jam production process from Pouteria cf. gardneriana Radlk, and evaluate the nutritional characteristics and functional properties of the jam.

\section{Materials and methods}

\subsection{Fruit material}

Guapeva fruit (Pouteria cf. gardneriana Radlk) were collected during the 2017-2018 season (between June and September) from plants that naturally occurred in the city of Palmas, Tocantins, Brazil. The fruits were harvested ripe and free from any uniformity or physical injuries. After sanitizing, pulps were extracted manually and kept at $-20^{\circ} \mathrm{C}$ until jam preparation.

\subsection{Jam preparation procedures}

The jams were processed in an open stainless-steel pan in an electric gas cooker. When the soluble solids content reached $65^{\circ} \mathrm{Brix}$, citric acid was incorporated, and the cooking was finished. The hot jams were packed into sterile $250 \mathrm{~mL}$ polyethylene flasks and weighed to obtain the yield of the final product, and after that, stored at $4{ }^{\circ} \mathrm{C}$. The passion fruit albedo used as a source of pectin was produced as described by Silva et al. (2012).

\subsection{Jam formulation -experimental planning}

A response surface with a complete factorial design $2^{3}$ was used to optimize the guapeva jams (Pouteria cf. gardneriana Radlk), according to the methodology described by Box \& Draper (1987) (Table 1). The experimental design aimed to evaluate the influence of the independent variables (citric acid concentration, pulp/sugar ratio, and albedo concentration as a source of 
Table 1. Experimental design $2^{3}$ for guapeva jams preparation.

\begin{tabular}{|c|c|c|c|c|c|c|}
\hline \multirow{2}{*}{ Essay } & \multicolumn{3}{|c|}{ Coded variables } & \multicolumn{3}{|c|}{ Real variables } \\
\hline & ${ }^{*} \mathrm{X} 1$ & ${ }^{* *} \mathrm{X} 2$ & ${ }^{* * *} \mathrm{X} 3$ & ${ }^{*} \mathrm{X} 1(\%)$ & ${ }^{* *} \mathrm{X} 2(\mathrm{w} / \mathrm{w})$ & ${ }^{* * *} \mathrm{X} 3(\%)$ \\
\hline 1 & +1 & +1 & +1 & 1 & $60 / 40$ & 3 \\
\hline 2 & -1 & -1 & +1 & 0 & $40 / 60$ & 3 \\
\hline 3 & +1 & -1 & +1 & 1 & $40 / 60$ & 3 \\
\hline 4 & -1 & +1 & +1 & 0 & $60 / 40$ & 3 \\
\hline 5 & +1 & +1 & -1 & 1 & $60 / 40$ & 0 \\
\hline 6 & -1 & +1 & -1 & 0 & $60 / 40$ & 0 \\
\hline 7 & +1 & -1 & -1 & 1 & $40 / 60$ & 0 \\
\hline 8 & -1 & -1 & -1 & 0 & $40 / 60$ & 0 \\
\hline 9 & 0 & 0 & 0 & 0,5 & $50 / 50$ & 1,5 \\
\hline 10 & 0 & 0 & 0 & 0,5 & $50 / 50$ & 1,5 \\
\hline 11 & 0 & 0 & 0 & 0,5 & $50 / 50$ & 1,5 \\
\hline
\end{tabular}

pectin) on $\mathrm{pH}$, total titratable acidity (TTA), non-reducing sugars (NRS), reducing sugars (RS), soluble solids (SS), yield, antioxidant activity (AA), vitamin C (VC), total phenolics $(\mathrm{TP}$,$) protein (\mathrm{PR})$, crude fiber $(\mathrm{CF})$, and texture (Hardness and Adhesiveness). The optimization model was estimated, including the interaction effect according to the determination coefficient $\left(\mathrm{R}^{2}\right)$. The estimations significance for the coefficients was analyzed to determine which factor contributed to the best fit of the model (significance level of 0.05).

\subsection{Analysis}

pH, titratable acidity, soluble solids, sugars and proximate composition

Guapeva jams were analyzed for $\mathrm{pH}$, total titratable acidity, total soluble solids, reducing and non-reducing sugars, moisture, ash, lipid, crude fiber, and proteins according to the AOAC methods (Association of Official Analytical Chemists, 2012) and Instituto Adolfo Lutz (2008). The total carbohydrate content was determined by difference (obtained by the difference between 100 and the sum of the percentages of moisture, protein, fats, and ash). Total energy value (TEV) (kcal/100g) was estimated using the conversion factors of Atwater \& Bryant (1906).

The color of jams was determined using the Konica Minolta colorimeter model CR400 (Minolta Corp., Osaka, Japan), as proposed by the Commission Internationale de l'Eclairage (1986).

\section{Bioactive compounds and antioxidant activity}

The jams were dried in an oven, ground, and subjected to immersion in an extractive solution of ethanol/water $(8: 2)$. The extracts contained $1 \mathrm{~g}$ and $5 \mathrm{~g}$ of sample for each $100 \mathrm{~mL}$ of the solution to determine phenolic compounds and antioxidant activity, respectively. The extracts were centrifuged for $15 \mathrm{~min}$ in the dark, filtered, and packed in amber glass bottles.

The total phenolic content was determined as described by Singleton \& Rossi (1965) with modifications. Briefly, $0.1 \mathrm{~mL}$ of jams extracts were added to a solution formed by $0.2 \mathrm{~mL}$ of Folin-
Ciocalteau (10\%), $2 \mathrm{~mL}$ of distilled water, and $1 \mathrm{~mL}$ of sodium carbonate $(4 \%)$. The mixture was homogenized and stored in the dark for 2 hours at room temperature. The absorbance was measured at $750 \mathrm{~nm}$.

Vitamin C content was determined by the colorimetric method, described by Strohecker \& Henning (1967), using 2,4-dinitrophenylhydrazine, and ascorbic acid as a standard. Total carotenoids were determined as proposed by Higby (1962).

The free radical scavenging ability was measured against 1,1-diphenyl-2-picrylhydrazyl (DPPH), according to BrandWilliams et al. (1995), with modifications by Rufino et al. (2010). The absorbance was measured at $515 \mathrm{~nm}$, and the antioxidant activity was expressed as $\mathrm{EC}_{50}$ (amount of antioxidant needed to reduce the initial DPPH concentration to $50 \%$ ).

To evaluate the reducing power of extracts, the ferric ion reducing antioxidant power (FRAP) assay was carried out as described by Rufino et al. (2010). A calibration curve was constructed using different concentrations of ferrous sulfate heptahydrate $(0-2000 \mu \mathrm{M})$. For each jam formulation, extracts were prepared with three dilutions, and then a $90 \mu \mathrm{L}$ aliquot of each dilution of the extracts was mixed with $270 \mu \mathrm{L}$ of distilled water and $2.7 \mathrm{~mL}$ of the FRAP reagent. The absorbance was measured at $595 \mathrm{~nm}$. The results were expressed in $\mu \mathrm{M}$ of ferrous sulfate/g of fruit or jam.

\subsection{Texture analysis}

The hardness and adhesiveness of jams were carried out in a Texturometer TA-XT2, P5S geometry, in the Multi-User Analysis Laboratory, at the Federal University of Goiás, Goiânia, GO, Brazil.

\subsection{Statistical analysis}

The results were expressed as mean values \pm standard deviation of the analyzes performed in triplicate and were treated using the Statistica 7.0 software. The coefficients and interaction between variables were observed, generating the response surface graph. The global desirability function was applied to determine the optimal proportions for each independent variable, optimizing the different response variables simultaneously to obtain the best formulation (Derringer \& Suich, 1980).

\section{Results and discussion}

The results without statistical significance were discarded for optimizing the jam production process, resulting in adjusted models using coded variables (Table 2).

Figure la showed that citric acid has an influence on and $\mathrm{pH}$; formulations without the addition of acid had values closer to the neutrality zone. According to Jackix (1988), for a stable gel formation, the $\mathrm{pH}$ should be between 3 and 3.2. pHs close to described by this author for guapeva jams were obtained in formulations with more significant citric acid addition (Figure 1a).

It can be seen in Figure $1 \mathrm{~b}$ that the citric acid variable influenced the final acidity content of jams, showing that independently of the pulp/sugar ratio, the products with the most significant 
acidity were those that contained citric acid. Guapeva is a fruit that has low acidity, which initially leads jam to values of 1 to 1.5 g. $100 \mathrm{~g}^{-1}$ for this parameter (Table 3). The results obtained in this work for guapeva jam then corroborate with that described by Aguiar et al. (2019). These authors observed that fruits with low acidity require the addition of acids to correct the $\mathrm{pH}$ and enable gel formation.

For the yield of the jam, the pulp/sugar ratio had results contrary to the citric acid variable, with formulations with higher proportions of sugar and pulp showing the best results (Figure 1c).

Table 2. Regression equations with coded variables, significance, and coefficients of determination of the complete models for the responses in dependent variables of guapeva jam.

\begin{tabular}{|c|c|c|c|}
\hline Response variables & Estimated model & Prob $>\mathrm{F}$ & $\mathrm{R}^{2}$ \\
\hline $\mathrm{pH}$ & $y=3.96-2.94 x+2.35 x^{2}+0.36 y-0.4 x y$ & 0.259134 & 0.932 \\
\hline Total titratable acidity $\left(\mathrm{g} .100 \mathrm{~g}^{-1}\right)$ & $y=0.58+1.42 x-0.74 x^{2}+0.32 y-0.267 x y$ & 0.258487 & 0.822 \\
\hline Reducing sugars (g.100 g ${ }^{-1}$ ) & $y=1.51+26.46 x_{1}-18.67 x^{2}+0.12 y-0.65 x y$ & 0.623748 & 0.764 \\
\hline Vitamin C (mg.100 g $\left.\mathrm{g}^{-1}\right)$ & $y=18.49-36.14 x+41.37 x^{2}+4.23 y+1.78 x y$ & 0.553725 & 0.794 \\
\hline FRAP ( $\mu$ mol of ferrous sulfate. $g^{-1}$ of jam) & $y=23.12+135.25 x-141.15 x^{2}+6.77 y+14.495 x y$ & 0.014799 & 0.939 \\
\hline Carotenoids & $y=0.09-0.73 x+0.99 x^{2}+1.08 y-0.92 x y$ & 0.217858 & 0.701 \\
\hline Protein $\left(\mathrm{g} .100 \mathrm{~g}^{-1}\right)$ & $y=2.65-3.51 x+1.90 x^{2}-0.14 y+0.15 x y$ & 0.158587 & 0.894 \\
\hline Crude fiber (g.100 g $\left.\mathrm{g}^{-1}\right)$ & $y=0.81+0.02 x-0.30 x^{2}+0.15 y+0.39 x y$ & 0.091943 & 0.769 \\
\hline Yield (\%) & $y=99.08-33.23 x+37.41 x^{2}-23.00 y+1.04 x y$ & 0.139457 & 0.901 \\
\hline Adhesiveness (N.s) & $y=-0.42+0.45 x-0.05 x+0.13 y-0.25 x y$ & 0.032456 & 0.778 \\
\hline Hardness (N.s) & $y=2.87-4.30 x+1.50 x^{2}-1.68 y+1.83 x y$ & 0.000180 & 0.951 \\
\hline $\mathrm{L}^{*}$ & $2 y=5.05+20.61 x-17.40 x^{2}+0.48 y-5.65 x y$ & 0.008280 & 0.831 \\
\hline$a^{*}$ & $y=6.814-10.25 x+7.236 x^{2}+.354 y+1.476 x y$ & 0.017780 & 0.779 \\
\hline
\end{tabular}

$\mathrm{F}=$ Factors statistically calculates at $95 \%$ confidence $(\mathrm{p} \leq 0.05)$ N.s $=$ Newton second

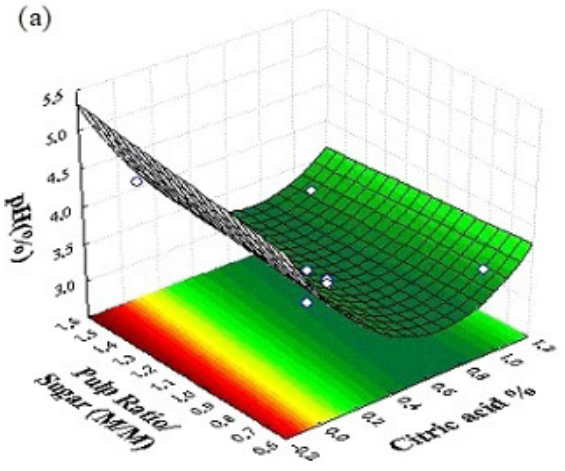

(c)

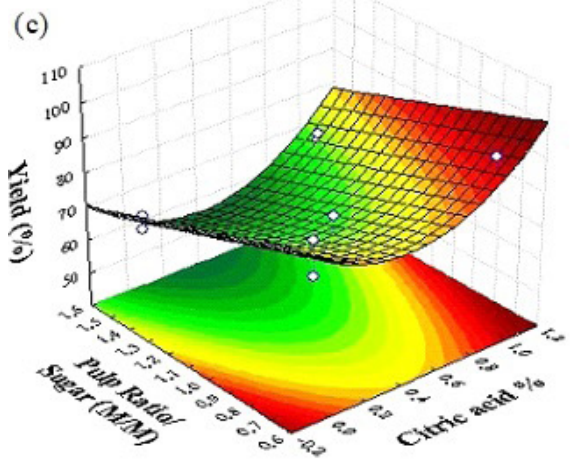

(b)

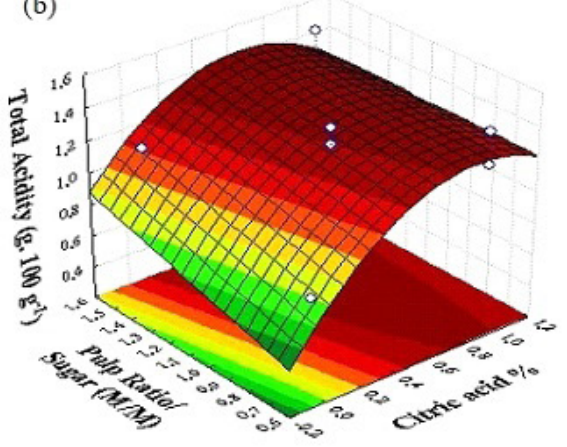

5
4.5
4
3.5

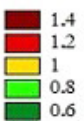

(d)

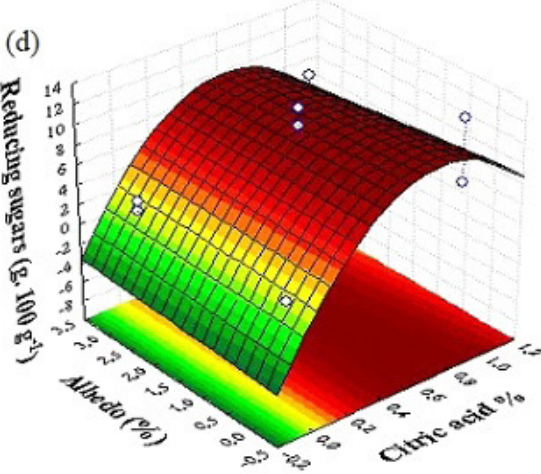

Figure 1. Response surface plots for (a) pH, (b) total titratable acidity, (c) yield interactions with pulp/sugar ratio and citric acid, and (d) reducing sugars $\left(\mathrm{g} .100 \mathrm{~g}^{-1}\right)$ interactions with citric acid and albedo. 


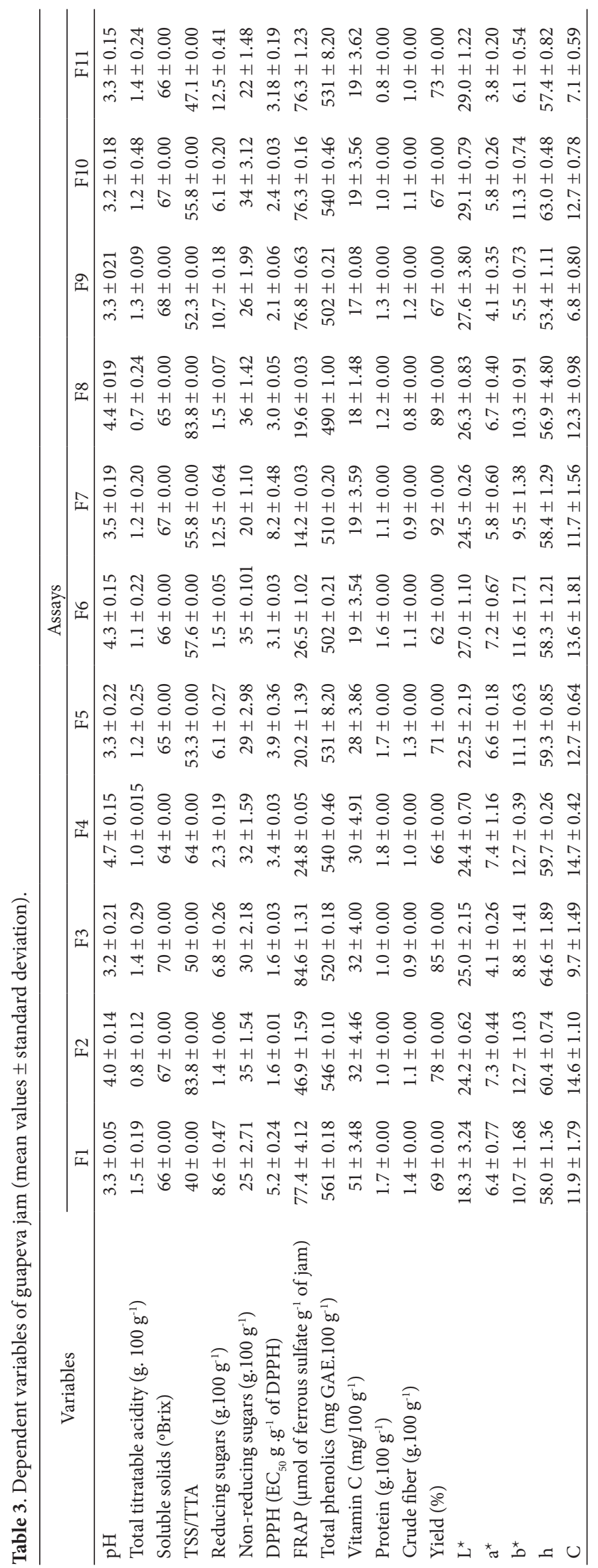


The amount of sugar added in the formulations is related to the content of soluble solids and interferes with the yield. The greater the amount of sugar added, the shorter the processing time and the yield of the jam will increase. This reduction in processing time, in turn, leads to cost savings.

The reducing sugar were influenced just by citric acid (Figure 1d). Higher values of reducing sugars were found in formulations with acid addition (Table 3), and this can be explained because a higher acidity favors the hydrolysis of sucrose. Acidity, combined with heating, causes the breakdown of sucrose into glucose and fructose, which, according to Martins et al. (2017), allows a better solubility of sugars when compared to pure sucrose. This partial inversion prevents the product from having an unpleasant texture at the end of processing.

The pulp/sugar variable was the only one that proved to generate influence about the protein content in jams (Figure 2a and Figure 2b). The formulations with the highest concentration of proteins have the highest proportion of pulp (Table 3 ) because of the content of this macronutrient in guapeva. The protein values in this work are higher than other fruit jellies, such as grape 0.27 g. $100 \mathrm{~g} \mathrm{~g}^{-1}$, blueberry $0.31 \mathrm{~g} .100 \mathrm{~g}^{-1}$, strawberry $0.41 \mathrm{~g} .100 \mathrm{~g}^{-1}$, and tamarind $0.68 \mathrm{~g} .100 \mathrm{~g}^{-1}$ (Mohd Naeem et al., 2017; Cardoso et al., 2012).

The pulp/sugar ratio influenced the crude fiber content for guapeva jams, independent of the acid concentration (Figure 2c).
As shown in Table 3, the formulations with the highest pulp concentration were the ones that showed the best results for crude fibers. Fiber values found for guapeva jams were higher than those described by Silva et al. (2018) for yellow and orange bocaiuva jams, which presented concentrations of 0.46 and 0.66 g. $100 \mathrm{~g}^{-1}$, respectively.

Figure 3 a shows that the variables albedo and citric acid influence the content of vitamin C. The contents of this compound increased in formulations with higher proportions of albedo and citric acid. According to Table 3, the formulation F1 has the highest vitamin $\mathrm{C}$ average (51 $\mathrm{mg} .100 \mathrm{~g}^{-1}$ ).

The total carotenoids were affected just by pulp/sugar ratio (Figure $3 \mathrm{~b}$ ), in spite of citric acid and albedo concentrations. The carotenoid levels found in this work ranged from 0.37 to $2.15 \mathrm{mg} .100 \mathrm{~g}^{-1}$ (Table 3), and these values are higher than those determined by Lemos et al. (2019) for a mixed jam with jaboticaba and acerola that showed results from 0.0016 to $0.0046 \mathrm{mg} .100 \mathrm{~g}^{-1}$. This behavior can be associated with the carotenoid content present in the guapeva fruit and the samples' exposure to high temperatures, and the variation of the components inserted in each formulation. As carotenoids are compounds studied as chemopreventive agents (Palioto et al., 2015), foods rich in these compounds, such as guapeva fruit and jam, can prevent diseases.

Regarding the sample's capacity to reduce ferric to ferrous ions measured by the FRAP method (Figure 4a), it is possible to
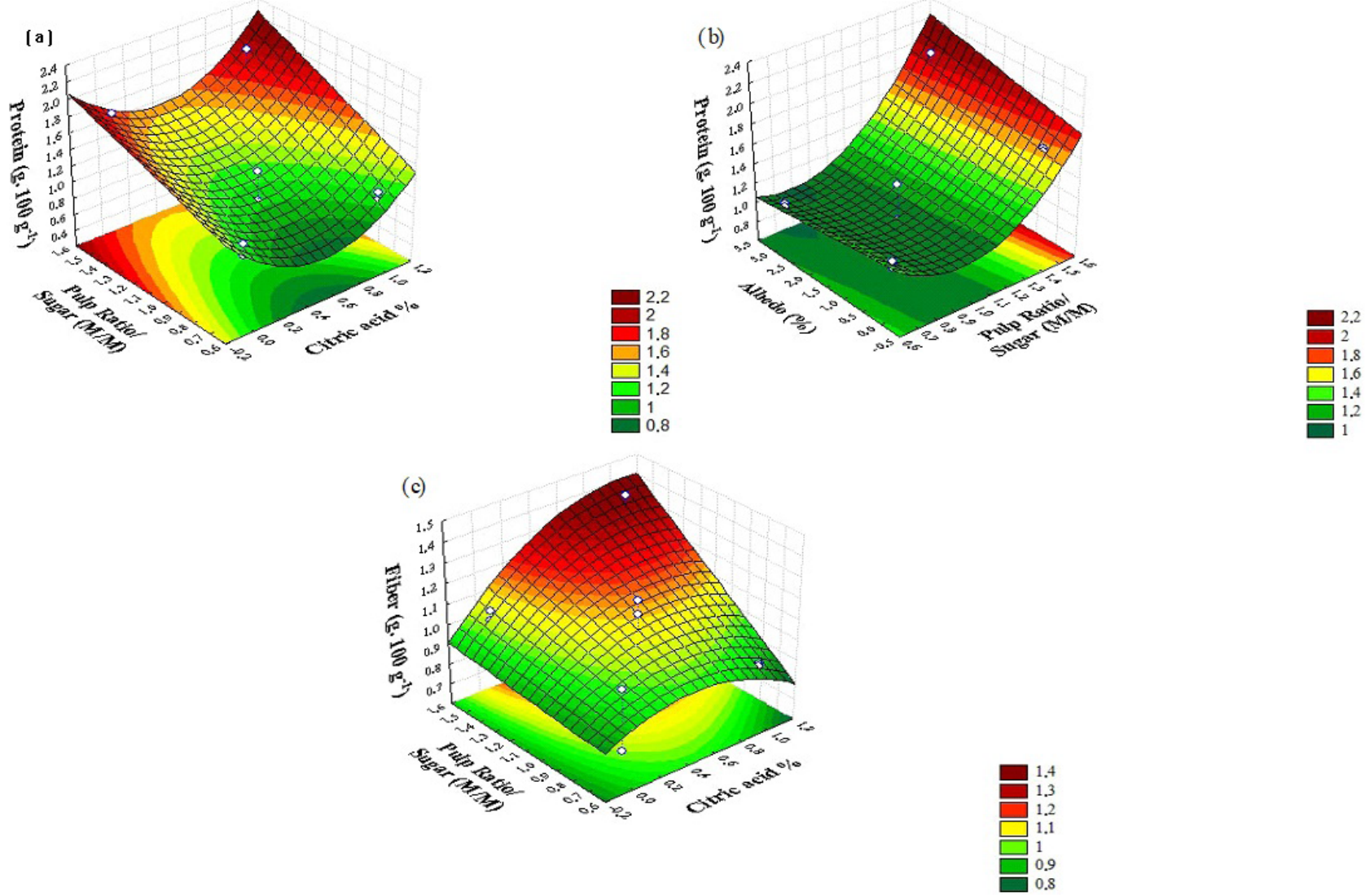

Figure 2. Response surface plots for (a) proteins $\left(\mathrm{g} .100 \mathrm{~g}^{-1}\right)$ interactions with albedo, (b) proteins $\left(\mathrm{g} .100 \mathrm{~g}^{-1}\right)$ interactions with citric acid, and (c) crude fiber $\left(\mathrm{g} .100 \mathrm{~g}^{-1}\right)$ interactions with pulp/sugar ratio and citric acid. 
observe that the citric acid variable had a significant influence, showing better results for formulations that contained acid in its composition (Table 3). In Figure $4 \mathrm{~b}$, the effect is related to the pulp/sugar ratio. In this case, formulations that contained a higher proportion of pulp showed better responses regardless of the albedo concentration. This behavior indicates that the antioxidant activity of guapeva jam is associated with the phenolic composition, since the antioxidant potential results from the synergistic effect between the phenolica compounds, vitamim $\mathrm{C}$, carotenoids and others bioactive compounds.

None studied variable had a significant influence on the antioxidant potential of guapeva jams. The formulations had antioxidant potential $\mathrm{EC}_{50}$ that varied from de 1.63 to $8.17 \mathrm{~g}$ of jam.g ${ }^{-1}$ of DPPH (Table 3). These results are relevant because, according to Cottica et al. (2011), as smaller the quantity in grams needed for free radical scavenging, the more expressive the antioxidant potential will be. The phenolic compounds had the same behavior that antioxidant potential, and presented values considered high, ranging from 502 to $561 \mathrm{mg}$ GAE. $100^{-1}$ (Table 3). These results demonstrate that even with thermal processing, it was possible to obtain jams rich in antioxidant compounds, phenolic compounds, and vitamin C. According to Kim et al. (2018), the cooking process facilitates the release of phenolic compounds, causing an increase in the quantity and availability of bioactive compounds.

The concentration of citric acid had an inverse influence on the $L^{*}$ value of guapeva jams (Figure $5 \mathrm{a}$ ). Thus, the $\mathrm{L}^{*}$ showed a negative linear relationship (Figure 5b). However, the quadratic is significantly larger, indicating that as the proportion of citric acid increases, the $\mathrm{L}^{*}$ tone is reduced. The jams become darker, which may be directly associated with the degradation of red pigments. In general, the color change in a food product during thermal processing may be related to the destruction of these dyes, especially the carotenoids, causing a non-enzymatic browning, such as the Millard reaction and oxidation of ascorbic acid (Jabbari et al ., 2018).
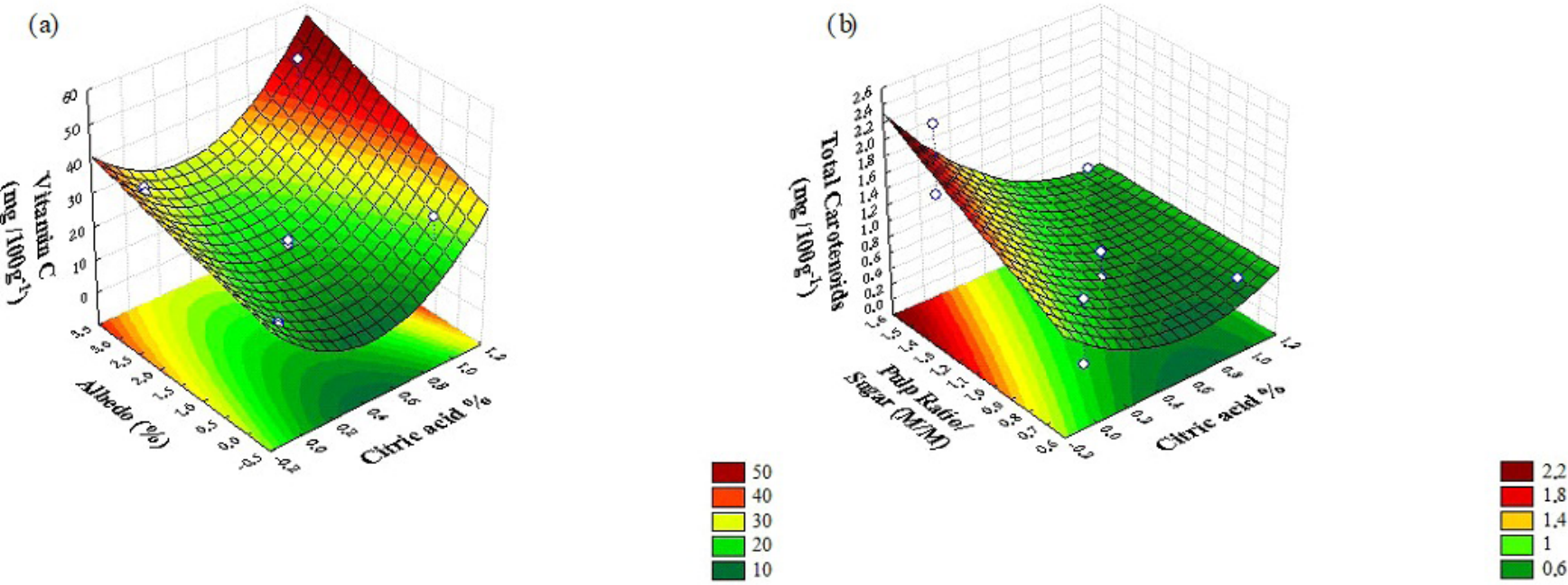

Figure 3. Response surface for (a) vitamin $\mathrm{C}\left(\mathrm{mg} .100 \mathrm{~g}^{-1}\right)$, and (b) total carotenoids $\left(\mathrm{mg} 100 \mathrm{~g}^{-1}\right)$ interactions with pulp/sugar ratio and citric acid.

(a)

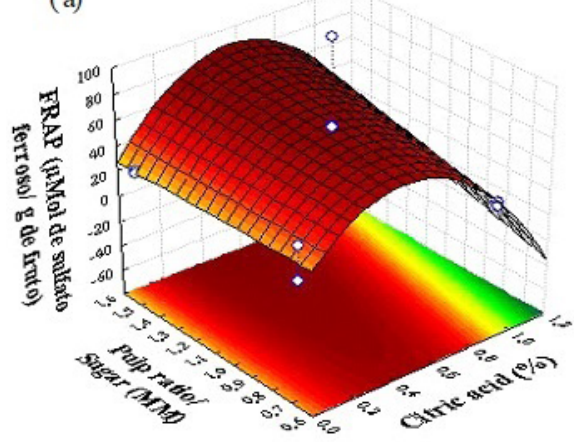

(b)

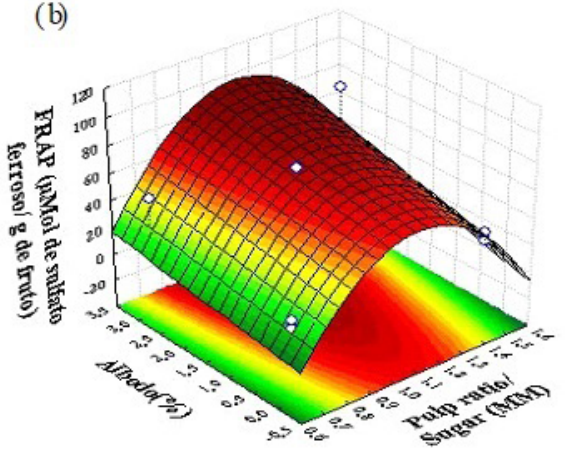

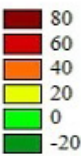

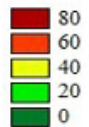

Figure 4. Response surface plots for (a) FRAP ( $\mu$ mol of ferrous sulfate. ${ }^{-1}$ of jam) interactions with pulp/sugar ratio and citric acid, and (b) FRAP ( $\mu \mathrm{mol}$ of ferrous sulfate. $\mathrm{g}^{-1}$ of jam) interactions with albedo and pulp/sugar ratio. 
For chroma ${ }^{\star} a$, there was a significant non-linear behavior for the action of citric acid (Figure 6a). However, despite not being significant at $\leq 0.05$, the regression coefficient attributed to the linear parameter for this variable was negative $(-2.44)$ (Figure 6b), indicating a tendency to reduce the red color, which can also be associated with the degradation of lycopene due to the reduction of the $\mathrm{pH}$ of the medium. The same behavior was determined by Kim \& Choi (2020), who attributed the degradation of lycopene to reduced $\mathrm{pH}$ levels, evidencing the significant influence of this parameter on the pigment's rapid degradation. The binary interaction between the pulp/sugar ratio and the citric acid concentration has a positive effect, indicating a tendency to increase the red color, which is probably related to the influence of the interaction of these factors with the rupture of the matrix membranes, releasing the lycopene and enhancing color.

The addition of citric acid in the jams influenced the adhesiveness so that the greater the addition of acid, the more adhesive the products will be (Figure 7a). For hardness (Figure 7b), the citric acid variable had an inverse influence compared the pulp/sugar ratio, showing that the greater the sugar addition in the lowest proportions of acid, the more force will be exerted on the jams. According to Szczesniak (2002) hardness is the necessary force for the material to reach a given deformation, this fact can be explained due to the decrease in the content of soluble solids, which were below $70^{\circ}$ Brix, indicating a high rate of water evaporation making the hardest and hardly breakable gel (Menezes et al., 2011). Central formulations (F9, F10, and F11) had values that correspond to the optimum point for adhesiveness and hardness (Table 3 ).

A desirability test was performed (Figure 8). This test presents the specifications for insertion in human food (minimum, optimal, and maximum) for the results from the optimized formulations considering the proportions of phenolic compounds and antioxidants. The desirability test indicated the best formulation of the mixture of citric acid at 1\%,60/40 pulp/sugar ratio, and albedo at $3 \%$, which corresponds to formulation F1. For F1, the results for phenolic compounds and antioxidant potential varied between $561 \mathrm{mg}$ GAE. (a)

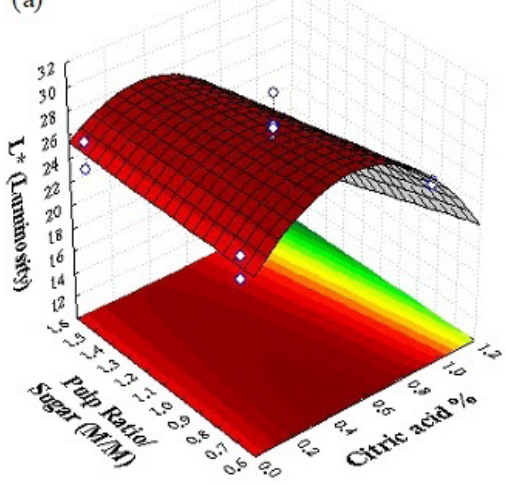

(b)

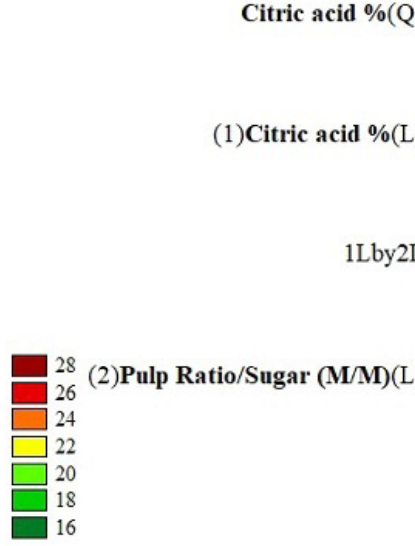

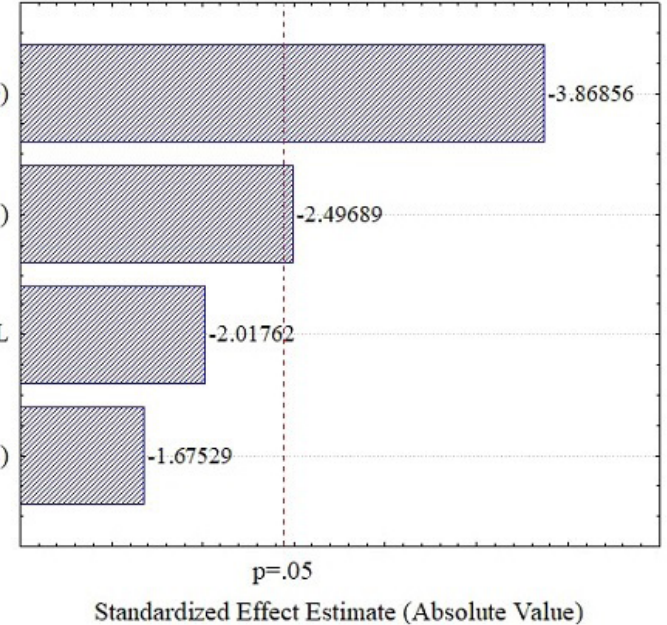

Figure 5. Response surface plots for (a) lightness $\left(L^{*}\right)$ and pareto $(b)$, interactions with pulp/sugar ratio and citric acid.

(a)

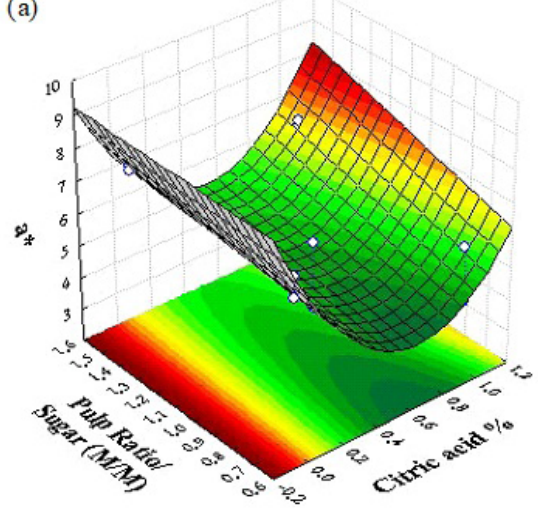

(b)

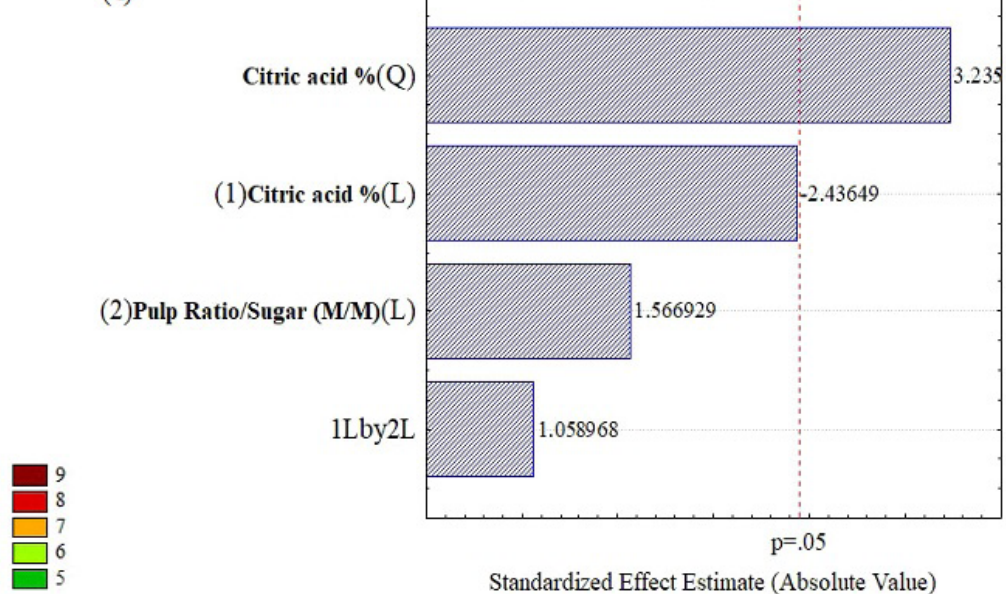

Figure 6. Response surface plots for (a) $a^{\star}$ red-green component and pareto (b), interactions with pulp/sugar ratio and citric acid. 
$100 \mathrm{~g}^{-1}$ and $5.2 \mathrm{~g}$ of jam. $\mathrm{g}^{-1} \mathrm{DPPH}$, respectively. According to Faller \& Fialho (2009), the average availability of polyphenols in Brazil, consumed in teas, coffees, and fruits, is $48.3 \mathrm{mg}$ per day.
Based on this, the insertion of guapeva jams in the population's diet can be considered a way to enhance the consumption of these compounds. (a)

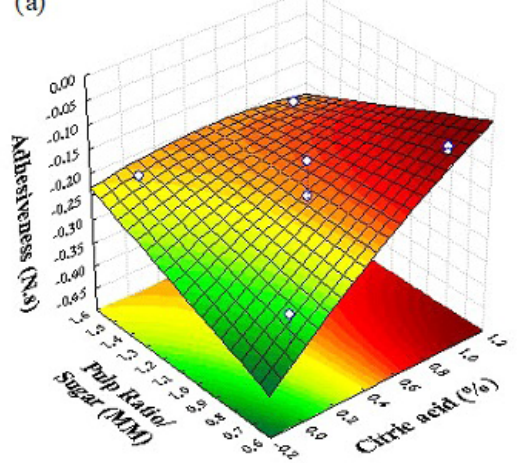

(b)

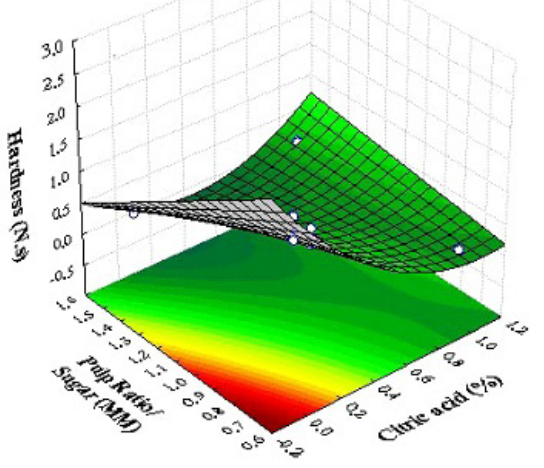

Figure 7. Response surface plots for (a) adhesiveness, and (b) hardness interactions with pulp/sugar ratio and citric acid.

\section{Profiles for Predicted Values and Desirability}

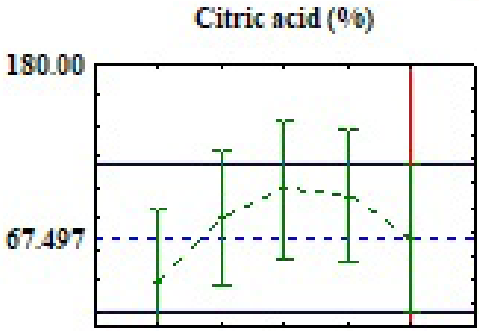

\section{Pulp ratio/ Sugar (MM)}
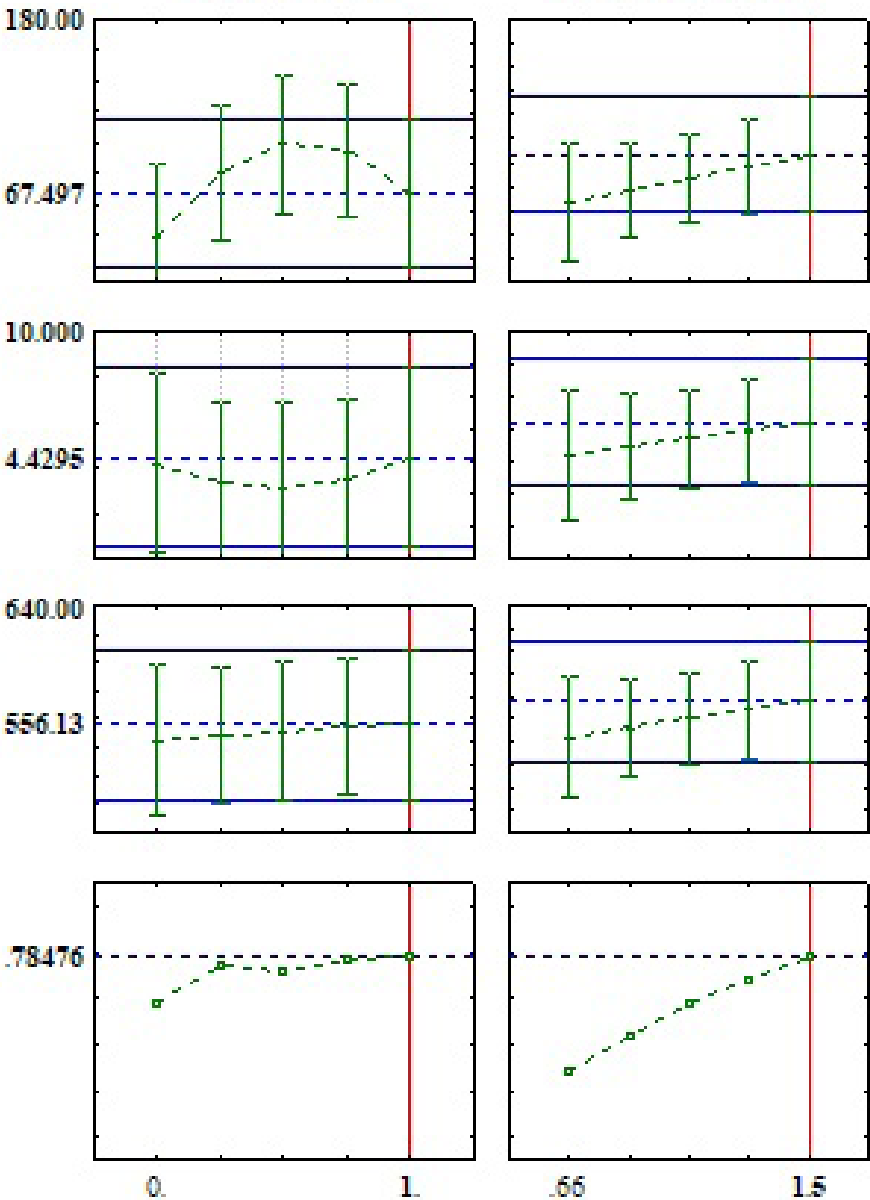
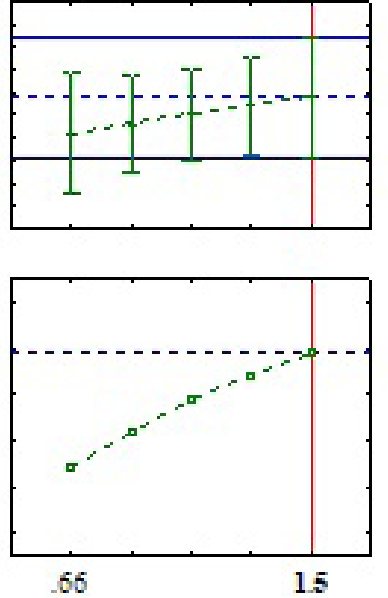

Albedo $(\%)$
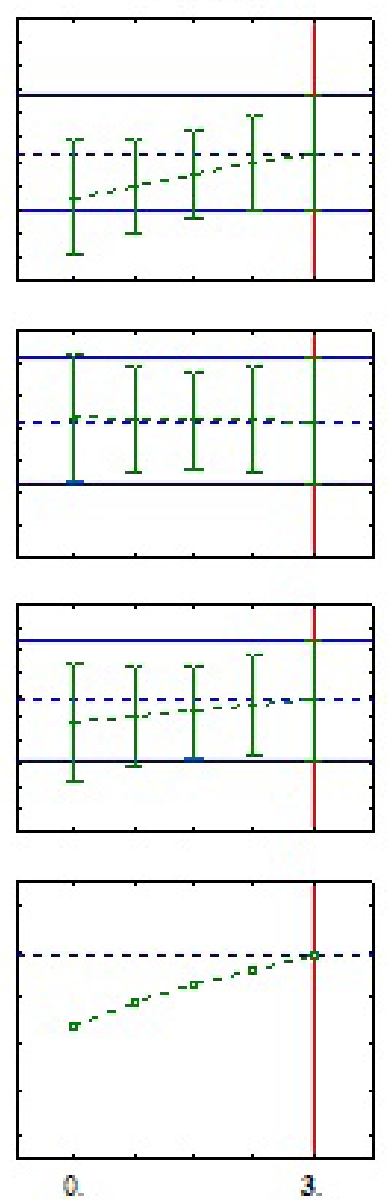

Decimbility
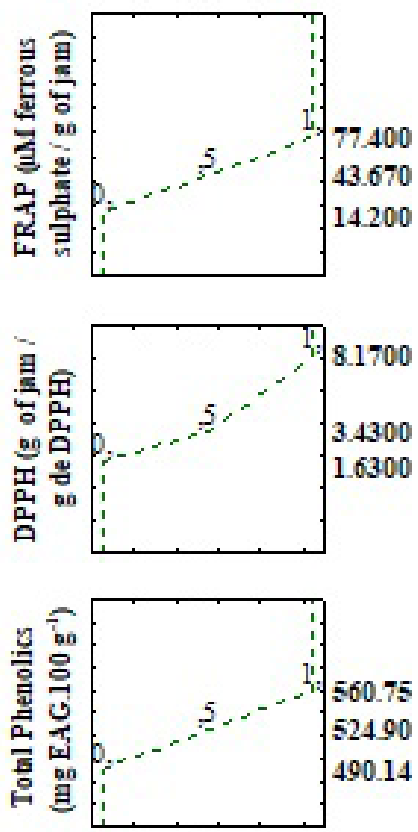

Figure 8. Profile of optimized values by desirability test for antioxidant potential and phenolic compounds in guapeva jams. 


\section{Conclusion}

The results indicated that the citric acid and pulp/sugar ratio positively influenced the analyzed responses. The guapeva jams formulations indicated as optimal for the parameters $\mathrm{pH}$, acidity, texture, and reducing sugars were F9, F10, and F11, showing better results for the ideal gel formation, and F1 with good percentages of phenolic compounds, antioxidant potential, fibers, proteins, and vitamin C. This work's results contribute to increased foods' insertion with a high nutritional value obtained from the Cerrado region's fruits in the consumer market.

\section{Acknowledgements}

The authors thank the Coordination for the Improvement of Higher Education Personnel (CAPES, Brazil), for the financial support offered through scholarships, the National Council for Scientific and Technological Development (CNPq, Brazil), and the Federal University of Tocantins for its infrastructure with the Graduate Program in Food Science and Technology (PPGCTA).

\section{References}

Aguiar, A. O., Rodrigues, D. D. S., de Souza, A. R., Soares, C. M. D. S., Ibiapina, A., Filho, A. A. D. M., \& Olivia, M. (2019). Use of Passion Fruit's Albedo as a Source of Pectin to Produce Araticum (Annona crassiflora Mart.) Preserves. Chemical Engineering (Albany, N.Y.), 75, 223-228.

Association of Official Analytical Chemists - AOAC. (2012). Official methods of analysis of the Association of Official Analytical Chemists. Arlington: AOAC.

Atwater, W. O., \& Bryant, A. P. (1906). The chemical composition of American food materials (No. 28). Washington: US Government Printing Office.

Barbosa, P. F. P., de Mendonça, P. P., Andrade, R. D. A., Aguiar, A. C. R., Chaves, A. R., da Costa, A. B., \& Silva, F. G. (2016). Application of polymeric nanoparticles for controlled release of ethanolic extract of guapeva leaves (Pouteria gardneriana Radlk) against Riphicephalus (Boophilus) microplus through in vitro studies. African Journal of Biotechnology, 15(49), 2778-2786. http://dx.doi.org/10.5897/ AJB2016.15230.

Box, G. E., \& Draper, N. R. (1987). Empirical model-building and response surfaces (Vol. 424). New York: Wiley.

Brand-Williams, W., Cuvelier, M. E., \& Berset, C. L. W. T. (1995). Use of a free radical method to evaluate antioxidant activity. LebensmittelWissenschaft + Technologie, 28(1), 25-30. http://dx.doi.org/10.1016/ S0023-6438(95)80008-5.

Cardoso, L. M., Batista, A. G., Hamacek, F. R., Dias, P. A., Rosa, B. C., Dessimoni, P. V., \& Dessimoni-Pinto, N. A. V. (2012). Quality of pulp and jellies of Tamarind from the Brazilian Cerrado. Alimentos e Nutrição, 23(3), 355-361.

Commission Internationale de 1'Eclairage - CIE. (1986). Colorimetry. Part 4: CIE $1976\left(L^{*} a^{*} b^{*}\right)$ System (2nd ed., Nº 15.2). Vienna: CIE.

Cottica, S. M., Sawaya, A. C., Eberlin, M. N., Franco, S. L., Zeoula, L. M., \& Visentainer, J. V. (2011). Antioxidant activity and composition of propolis obtained by different methods of extraction. Journal of the Brazilian Chemical Society, 22(5), 929-935. http://dx.doi. org/10.1590/S0103-50532011000500016.
Derringer, G., \& Suich, R. (1980). Simultaneous optimization of several response variables. Journal of Quality Technology, 12(4), 214-219. http://dx.doi.org/10.1080/00224065.1980.11980968.

Faller, A. L. K., \& Fialho, E. (2009). Disponibilidade de polifenóis em frutas e hortaliças consumidas no Brasil. Revista de Saude Publica, 43(2), 211-218. http://dx.doi.org/10.1590/S0034-89102009005000010. PMid:19225692.

Higby, W. K. (1962). A simplified method for determination of some aspects of the carotenoid distribution in natural and carotene-fortified orange juice. Journal of Food Science, 27(1), 42-49.

Instituto Adolfo Lutz - IAL. (2008). Métodos físico-químicos para análise de alimentos: normas analíticas. São Paulo: IAL.

Jabbari, S. S., Jafari, S. M., Dehnad, D., \& Shahidi, S. A. (2018). Changes in lycopene content and quality of tomato juice during thermal processing by a nanofluid heating medium. Journal of Food Engineering, 230, 1-7. http://dx.doi.org/10.1016/j.jfoodeng.2018.02.020.

Jackix, M. H. (1988). Doces, geléias e frutas em calda. São Paulo: Ícone.

Kim, J., \& Choi, S. J. (2020). Improving the stability of lycopene from chemical degradation in model beverage emulsions: impact of hydrophilic group size of emulsifier and antioxidant polarity. Foods, 9(8), 971. http://dx.doi.org/10.3390/foods9080971. PMid:32707864.

Kim, H. J., Lee, J. H., Lee, B. W., Lee, Y. Y., Lee, B. K., et al (2018). Effect of Cooking Methods on Phenolic Compounds and their Radical Scavenging Activity of Cooked Mixed Grain Rice/Sorghum Mixtures. Journal of Nutrition \& Food Sciences, 8, 713

Lemos, D. M., Rocha, A. P. T., Gouveia, J. P. G., Oliveira, E. N. A., Sousa, E. P., \& Silva, S. F. (2019). Elaboração e caracterização de geleia prebiótica mista de jabuticaba e acerola. Brazilian Journal of Food Technology, 22, 22. http://dx.doi.org/10.1590/1981-6723.09818.

Li, Y., Zhang, J. J., Xu, D. P., Zhou, T., Zhou, Y., Li, S., \& Li, H. B. (2016). Bioactivities and health benefits of wild fruits. International Journal of Molecular Sciences, 17(8), 1258. http://dx.doi.org/10.3390/ ijms17081258. PMid:27527154.

Malta, L. G., Tessaro, E. P., Eberlin, M., Pastore, G. M., \& Liu, R. H. (2013). Assessment of antioxidant and antiproliferative activities and the identification of phenolic compounds of exotic Brazilian fruits. Food Research International, 53(1), 417-425. http://dx.doi. org/10.1016/j.foodres.2013.04.024.

Martins, G. A. S., Ferrua, F. Q., Borges, S. V., Alves, D. G., \& de Jesus Almeida, L. (2017). Determination of shelf life by accelerated tests in banana preserves. Magistra, 28(2), 149-156.

Menezes, C. C., Borges, S. V., Ferrua, F. Q., Vilela, C. P., \& Carneiro, J. D. D. S. (2011). Influence of packaging and potassium sorbate on the physical, physicochemical and microbiological alterations of guava preserves. Food Science and Technology (Campinas), 31(3), 674-680. http://dx.doi.org/10.1590/S010120612011000300019.

Mohd Naeem, M. N., Mohd Fairulnizal, M. N., Norhayati, M. K., Zaiton, A., Norliza, A. H., Wan Syuriahti, W. Z., Mohd Azerulazree, J., Aswir, A. R., \& Rusidah, S. (2017). The nutritional composition of fruit jams in the Malaysian market. Journal of the Saudi Society of Agricultural Sciences, 16(1), 89-96. http://dx.doi.org/10.1016/j. jssas.2015.03.002.

Morzelle, M., Bachiega, C., De Souza, P., Boas, C., \& Lamounier, B. (2015). Chemical and physical characterization of fruits from Cerrado: curriola, gabiroba and murici. Revista Brasileira de Fruticultura, 37(1), 96-103. http://dx.doi.org/10.1590/0100-2945-036/14.

Palioto, G. F., Silva, C. F. G., Mendes, M. P., Almeida, V. V., Rocha, C. L. M. S. C., \& Tonin, L. T. D. (2015). Composição centesimal, compostos 
bioativos e atividade antioxidante de frutos de Morinda citrifolia Linn (noni) cultivados no Paraná. Revista Brasileira de Plantas Medicinais, 17(1), 59-66. http://dx.doi.org/10.1590/1983-084X/13_066.

Rufino, M. S., Alves, R. E., de Brito, E. S., Pérez-Jiménez, J., SauraCalixto, F., \& Mancini-Filho, J. (2010). Bioactive compounds and antioxidant capacities of 18 non-traditional tropical fruits from Brazil. Food Chemistry, 121(4), 996-1002. http://dx.doi.org/10.1016/j. foodchem.2010.01.037.

Schiassi, M. C. E. V., Souza, V. R., Lago, A. M. T., Campos, L. G., \& Queiroz, F. (2018). Fruits from the Brazilian Cerrado region: physico-chemical characterization, bioactive compounds, antioxidant activities, and sensory evaluation. Food Chemistry, 245, 305-311. http://dx.doi. org/10.1016/j.foodchem.2017.10.104. PMid:29287376.

Silva, E. P., Abreu, W. C., Gonçalves, O. A., Damiani, C., \& Vilas Boas, E. V. B. (2017). Characterization of chemical and mineral composition of marolo (Annona crassiflora Mart) during physiological development. Food Science and Technology (Campinas), 37(1), 13-18. http://dx.doi. org/10.1590/1678-457x.0107.

Silva, I. G., Martins, G. A. D. S., Borges, S. V., Marques, G. R., \& Regis, I. S. (2012). Influence of passion fruit albedo, citric acid, and the pulp/sugar ratio on the quality of banana preserves. Food Science and Technology (Campinas), 32(2), 267-273. http://dx.doi.org/10.1590/ S0101-20612012005000038.

Silva, V. M. D., Campos, R. P., Borsato, A. V., Candido, C. J., \& Donadon, J. R. (2018). Bocaiuva jelly: preparation, physicochemical and sensory evaluation. Revista Brasileira de Fruticultura, 40(5). http://dx.doi. org/10.1590/0100-29452018846.

Singleton, V. L., \& Rossi, J. A. (1965). Colorimetry of total phenolics with phosphomolybdic-phosphotungstic acid reagents. American Journal of Enology and Viticulture, 16(3), 144-158.

Siqueira, A. P. S., Oliveira, J. D. M., Machado, D. R., Jr., \& Lourenço, M. F. D. C. (2017). Chemical characterization and antioxidant capacity of guapeva. Revista Brasileira de Fruticultura, 39(spe), 39. http:// dx.doi.org/10.1590/0100-29452017584.

Strohecker, R., \& Henning, H. M. (1967). Análisis de vitaminas, métodos comprovados. Madrid: Paz Montalvo.

Szczesniak, A. S. (2002). Texture is a sensory property. Food Quality and Preference, 13(4), 215-225. http://dx.doi.org/10.1016/S09503293(01)00039-8. 